University of Nebraska - Lincoln

DigitalCommons@University of Nebraska - Lincoln

\title{
Animal foraging as a mechanism for sediment movement and soil nutrient development: Evidence from the semi-arid Australian woodlands and the Chihuahuan Desert
}

\author{
David J. Eldridge \\ University of NSW, d.eldridge@unsw.edu.au \\ Terry B. Koen \\ Department of Environment, Climate Change and Water, Terry.Koen@environment.nsw.gov.au \\ Aaron Killgore \\ New Mexico State University, akillgore@onda.org \\ Niki Huang \\ University of NSW \\ Walter G. Whitford \\ USDA-ARS Jornada Experimental Range
}

Follow this and additional works at: https://digitalcommons.unl.edu/usdaarsfacpub

Part of the Agricultural Science Commons

Eldridge, David J.; Koen, Terry B.; Killgore, Aaron; Huang, Niki; and Whitford, Walter G., "Animal foraging as a mechanism for sediment movement and soil nutrient development: Evidence from the semi-arid Australian woodlands and the Chihuahuan Desert" (2012). Publications from USDA-ARS / UNL Faculty. 849.

https://digitalcommons.unl.edu/usdaarsfacpub/849

This Article is brought to you for free and open access by the U.S. Department of Agriculture: Agricultural Research Service, Lincoln, Nebraska at DigitalCommons@University of Nebraska - Lincoln. It has been accepted for inclusion in Publications from USDA-ARS / UNL Faculty by an authorized administrator of DigitalCommons@University of Nebraska - Lincoln. 


\title{
Animal foraging as a mechanism for sediment movement and soil nutrient development: Evidence from the semi-arid Australian woodlands and the Chihuahuan Desert
}

\author{
David J. Eldridge ${ }^{\mathrm{a}, *}$, Terry B. Koen ${ }^{\mathrm{b}}$, Aaron Killgore ${ }^{\mathrm{c}, 1}$, Niki Huang ${ }^{\mathrm{a}}$, Walter G. Whitford ${ }^{\mathrm{d}}$ \\ a Evolution and Ecology Research Centre, School of Biological, Earth and Environmental Sciences, University of NSW, Sydney, NSW, 2052, Australia \\ b Department of Environment, Climate Change and Water, P.O. Box 445, Cowra, NSW, 2794, Australia \\ ${ }^{c}$ Department of Fishery and Wildlife Science, New Mexico State University, Las Cruces, NM 88003, USA \\ d USDA-ARS Jornada Experimental Range, PO Box 3003, MSC 3JER, New Mexico State University, Las Cruces, NM, USA, 88003
}

\section{A R T I C L E I N F O}

\section{Article history:}

Received 6 March 2011

Accepted 3 April 2011

Available online 29 June 2011

\section{Keywords:}

Foraging

Soil movement

Biopedturbation

Rodents

Vertebrates

Soil formation

Patchiness

Arid

\begin{abstract}
A B S T R A C T
An emerging area of interest in geomorphology over the past two decades has been the effects of biota on ecosystem processes. We examined the roles of a range of vertebrates on soil disturbance in two markedly different environments, the semi-arid woodland of eastern Australia and a Chihuahuan Desert grassland-shrubland in the south-western United States. Foraging pits of soil-disturbing vertebrates varied markedly from small scratchings of heteromyid (mainly Dipodomys spp.) rodents $\left(1.8 \times 10^{-4} \mathrm{~m}^{3}\right)$ to deep $\left(1.0 \times 10^{-2} \mathrm{~m}^{3}\right)$ excavations of the burrowing bettong (Bettongia leuseur) and greater bilby (Macrotis lagotis). Vertebrates moved substantial volumes of soil in both environments, and activity was highly temporally and spatially variable. At large spatial scales, soil disturbance by echidnas (Tachyglossus aculeatus) and Gould's sand goannas (Varanus gouldii) was substantially greater in communities dominated by shrubs, and where domestic livestock had been excluded. Heteromyid rodents tended to excavate more foraging pits in coarse-textured vegetation communities (both grasslands and shrublands). In both environments, foraging was concentrated close to perennial plants such as grass tussocks and tree canopies rather than in the interspaces. Foraging pits of Chihuahuan desert animals tended to be higher in labile carbon and support greater levels of infiltration, though this was plant community-dependent. Overall our results indicate that animal foraging is an important geomorphic mechanism capable of mobilizing substantial volumes of soil in arid and semi-arid environments and with potential effects on soil function.
\end{abstract}

(c) 2011 Elsevier B.V. All rights reserved.

\section{Introduction}

Arid and semi-arid systems are characterized by a patchy (heterogeneous) distribution of resources. Patchiness in soils and vegetation exists at multiple spatial scales ranging from that existing around individual plants to whole landscapes (e.g. Dunkerley and Brown, 1995; Bochet et al., 1999). Resource patchiness manifests itself as two markedly different patch types, those that accumulate resources (termed 'fertile patches' or 'fertile islands') that are superimposed within a resource-poor matrix. This uneven distribution of resources leads to increased ecosystem diversity and productivity (Noy-Meir, 1973). While patchiness is driven largely by geomorphic (abiotic) processes of erosion and deposition, biotic processes are also important

\footnotetext{
* Corresponding author. Tel.: +61 29385 2194; fax: +6129385 1558.

E-mail addresses: d.eldridge@unsw.edu.au (D.J. Eldridge),

Terry.Koen@environment.nsw.gov.au (T.B. Koen), akillgore@onda.org (A. Killgore).

${ }^{1}$ Present address: John Day Coordinator at Oregon Natural Desert Association, 16 NW Kansas Avenue, Bend OR 97701, USA.
}

(Eldridge et al., 2011). One such biotic process is soil disturbance by animals, which occurs during foraging, resting, or creating and maintaining habitat.

Soil disturbance by animals modulates key ecosystem flows of water, sediment and nutrients, ultimately controlling the availability and distribution of essential resources to other organisms (Jones et al., 1997). Small mammals influence ecosystem properties and processes by burrowing, foraging for insect larvae, and by excavating seed caches. These activities disturb surface crust integrity, create voids and depressions that trap seeds and organic material, and mix excavated soil with intact surface soil (Whitford and Kay, 1999). The foraging pits of rodents and small mammals function as resource traps for soil, litter, feces, seed and nutrients (Boeken et al., 1995; Eldridge, 2004; Garkaklis et al., 2004; James and Eldridge, 2007). Larger structures such as mounds and surface accumulations created by animals alter infiltration rates, surface insolation and soil physico-chemical processes, thereby affecting the distribution of vegetation (Dangerfield et al., 1998; Nkem et al., 2000; Lavelle et al., 2006). Disturbed soil material is often redistributed by wind or water erosion, ultimately contributing to downslope sediment loads (Elkins et al., 1986; Nash and Whitford, 1995; Wagner et al., 1997; Eldridge and Myers, 2000; Snyder et al., 2002). 
Despite the relatively rich literature on soil disturbance by a range of animals (e.g. Reichman and Smith, 1990; Meadows and Meadows, 1991; Whitford and Kay, 1999), few if any studies have considered multi-temporal (or multi-spatial) shifts in soil disturbance in response to altered plant community structure. Changes in plant communities can result from, for example, altered intensity of land use such as increased (or decreased) stocking rates, or increases in the density of woody plants (shrub encroachment) through anthropogenic or natural causes. Grazing by domestic livestock generally leads to reduced plant production, shifts in the balance of palatable to unpalatable plants, and eventually, structural and functional changes to the soils such as compaction and reduced infiltration capacity (Eldridge et al., 2011). Many of these changes are expected to impact upon soil disturbing animals because they alter habitat characteristics for animals, prey levels, and the chances of locating invertebrate prey or seed. Trampling by livestock, for example, has been shown to alter soil movement by heteromyid rodents around livestock watering points, though temporal effects were more influential (e.g. Eldridge and Whitford, 2009).

Encroachment of woody plants into grasslands, and conversion of open woodlands and grassland to shrubland, have been widelyreported over the past century (van Auken, 2009; Archer, 2010). Encroachment is thought to result from overgrazing, recovery from previous human disturbances, reduced frequency of wildfire, and increases in atmospheric carbon dioxide concentrations (Coetzee et al., 2008; van Auken, 2009; Archer, 2010). Because encroachment alters both the structure and composition of plant communities, it is likely to have substantial effects on the habitat values for many soildisturbing animals (Eldridge et al., 2009) and therefore, on subsequent rates of soil movement or soil formation. In the semi-arid woodlands of eastern Australia, extensive areas of Eucalypt-dominated open woodland are dominated by native shrubs at densities higher than those existing prior to European settlement (Noble, 1997). Similarly, in the western United States, extensive areas of black grama (Bouteloua spp.) grasslands have been encroached by mesquite (Prosopis glandulosa) and creosote bush (Larrea tridentata). The overall effect of shrub encroachment has been to alter plant cover and distribution, and soil nutrient and carbon levels, and therefore alter the habitat value for ground-disturbing vertebrates (e.g. Kerley and Whitford, 2009; Archer, 2010). Some of these changes may increase the foraging activity of rodents, particularly, when increasing shrubs lead to greater seed resources (e.g. Longland, 1995), while others can result in reduced foraging, and therefore soil disturbance, when increasing shrub density leads to reductions in invertebrates that are preyed upon by animals such as squirrels and badgers.

Despite extensive research on disturbance by soil-disturbing animals (e.g. Butler, 1995), we know relatively little about how animal disturbances might change in relation to changing plant community composition and the nature of temporal changes in soil movement in a range of communities. In this paper we examine the movement of soils by different suites of soil-disturbing vertebrates in two markedly different environments; 1 ) the semi-arid Eucalypt woodlands of eastern Australia, which are inhabited by medium-sized (1000 to $7000 \mathrm{~g}$ ) vertebrates, and 2) the desert grasslands and shrublands of the northern Chihuahuan Desert in south-western USA, dominated by small-bodied $(<200 \mathrm{~g})$ fossorial, generally heteromyid, rodents. We chose these two animal groups for three reasons; they are common vertebrates of the two systems, they forage (or cache) extensively in the soil, and the morphology of their disturbances varies greatly. Different sized pits will therefore yield different masses of soil, and the effects of this soil removal on ecosystem processes are likely to differ. We also used these two animal groups to ask whether there are similarities in soil removal between the two continents and vegetation communities, which both show evidence of shrub encroachment and therefore potential effects on surface soil disturbance.

Our study aims to answer three research questions: 1) do foraging pits vary among land uses, i.e. are there differences in the density and size of foraging pits between areas that are grazed and ungrazed by domestic livestock? (Australia only), 2) are there differences in soil movement among different vegetation communities? In particular, is soil movement greater in areas of encroaching shrubs (e.g. swales and cleared woodlands in Australia, and creosote bush, mesquite dunefields and tarbush playa in the Chihuahuan Desert) than in the grassland or open woodland communities?, 3) are there differences in foraging, and thus soil movement, among different patches (tree hummocks, shrubs hummocks, grass tussocks, log mounds) or in relation to proximity to these patches (e.g. close to the canopy or in the interspaces)? Finally we consider the potential effects of soil disturbance by animals by examining two soil processes; the infiltration of water and changes in labile soil carbon (Chihuahuan Desert). Since the effects of bioturbation on infiltration and soil carbon are related to soil texture, the results should apply to arid regions in general since fine-textured soils require excessive energy expenditure for burrowing and digging.

\section{Materials and methods}

\subsection{Descriptions of the study areas}

The Australian data were collected in four different vegetation communities in far south-western NSW ( $32^{\circ} 12^{\prime} \mathrm{S}, 141^{\circ} 10^{\prime} \mathrm{E}$; Table 1$)$; 1) linear dunes dominated by Eucalypts; 2) inter-dunal swales; 3) plains with an intact tree community, and 4) plains from which the trees had been cleared in the early 1960s, and were now dominated by a dense patches of shrubs (Fig. 1). The dunes were predominantly west-east trending, of Quaternary alluvium, and characterized by calcareous and siliceous sands (Rudosols). They were separated by inter-dunal swales and plains, up to $500 \mathrm{~m}$ wide, of loamy, calcareous soils (Calcarosols). Vegetation on the dunes is dominated by open mallee (Eucalyptus spp.) woodland with a spinifex (Triodia scariosa

Table 1

Biotic and abiotic features of the four sites in eastern Australia and six sites in the Chihuahuan Desert.

\begin{tabular}{|c|c|c|c|c|}
\hline Community name & Dominant plant species & Surface texture & Slope $(\%)$ & US soil classification \\
\hline \multicolumn{5}{|l|}{ Australian sites } \\
\hline Mallee dunes & Eucalyptus spp., Triodia scariosa ssp. scariosa & Sand to loamy sand & $0-2$ & Rudosols \\
\hline Inter-dunal swales & Senna artemisioides, Dodonaea viscosa & Loamy sand & $0-1$ & Rudosols \\
\hline Plains uncleared & Casuarina pauper, Myoporum platycarpum, Maireana spp. & Loam to clay loam & 0.5 & Calcarosols \\
\hline Plains cleared & Eremophila sturtii, Senna artemisioides, Dodonaea viscosa & Loam to clay loam & 0.5 & Calcarosols \\
\hline \multicolumn{5}{|l|}{ United States sites } \\
\hline Black grama grassland & Bouteloua eriopoda, Sporobolus spp. Pleuraphis mutica & Sandy clay loam to sandy loam & $1-3$ & Thermic Calciargid \\
\hline Creosote bush shrubland & Larrea tridentata & Coarse sandy to sandy loam & $3-5$ & Thermic Ustic Haplargid \\
\hline Mesquite coppice dunefield & Prosopis glandulosa & Loamy sand & $0-3$ & Thermic Ustic Haplargid \\
\hline Banded burro grass swale & Scleropogon brevifolia, Pleuraphis mutica, Flourensia cernua & Loam to sandy clay & $0-2$ & Thermic Ustic Calciargid \\
\hline Tobosa grass swale & Pleuraphis mutica & Loam to sandy clay & $0-1$ & Thermic Ustic Haplocalcid \\
\hline Tarbush shrubland & Flourensia cernua & Loam to sandy clay & $0-2$ & Thermic Ustic Calciargid \\
\hline
\end{tabular}



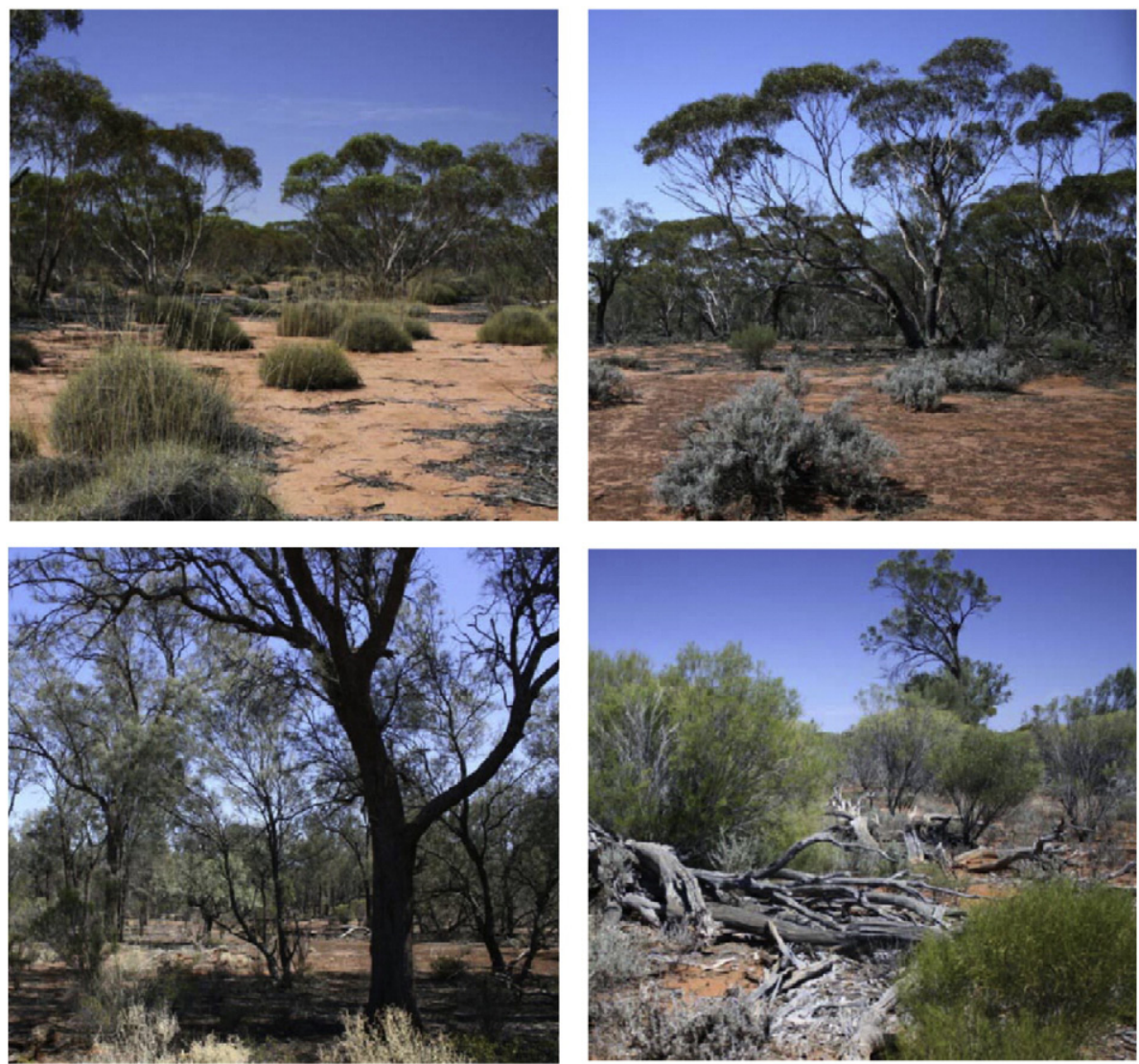

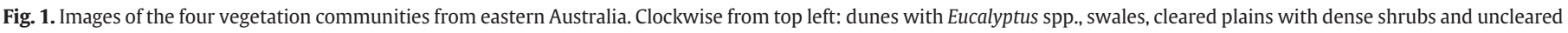
plains. Photographs: Niki Huang.

ssp. scariosa) understorey and a variable cover of shrubs such as punty bush (Senna artemisioides) and narrow-leaved hopbush (Dodonaea viscosa). The plains vegetation is dominated by scattered belah (Casuarina pauper) and sugarwood (Myoporum platycarpum), and a variable cover of shrubs such as punty bush, hopbush, turpentine (Eremophila sturtii), pinbush wattle (Acacia burkittii) and assorted bluebushes (Maireana spp.), depending on whether trees had been removed. Overall, shrubs were extremely dense ( $\sim 50 \%$ cover) over large areas of the plains where trees have been removed. The climate is semi-arid, with cool winters (mean $\leq 17^{\circ} \mathrm{C}$ ) and hot summers (mean $30^{\circ} \mathrm{C}$ ). Rainfall averages $250 \mathrm{~mm} \mathrm{yr}^{-1}$.

Studies in the United States were conducted in the northern Chihuahuan Desert at the USDA-ARS Jornada Experimental Range and the New Mexico State University Chihuahuan Desert Rangeland Research Centre, near Las Cruces, New Mexico, USA $\left(32^{\circ} 37^{\prime} \mathrm{N}\right.$, $106^{\circ} 40^{\prime} \mathrm{W}$ ). We studied animal disturbances within six vegetation communities (Table 1). Three communities occur on fine-textured soils in a basin plain landscape: 1) the black grama (Bouteloua eriopoda) grassland on fine-textured soils, 2 ) mesquite ( $P$. glandulosa) on coppice dunes, and 3) tobosa grass (Pleuraphis mutica)alkali sacaton (Sporobolus airoides) swales (Fig. 2). Extensive overgrazing of the basin plains landscape over the last century has resulted in the encroached by mesquite and other shrubs into large areas of grasslands in the southern basin (Eldridge et al., 2009). The other three vegetation communities occurred on the lower slopes of the watershed: 4) creosote bush (L. tridentata) on shallow, coarsetextured, gravelly piedmont soils, 5) tarbush (Flourensia cernua) slopes on fine-textured clay-loams, and 6) banded swales dominated by burro grass (Scleropogon brevifolia, Fig. 2).

The other three vegetation communities; iv) creosote bush (L. tridentata) on shallow, coarse-textured, gravelly piedmont soils, v) tarbush (F. cernua) slopes on fine-textured clay-loams, grading into vi) banded swales dominated by burro-grass (S. brevifolia), occurred on the lower slopes of the watershed.

\subsection{Does soil movement differ in relation to land use and patch type?}

We surveyed the occurrence of foraging pits of the short-beaked echidna (Tachyglossus aculeatus) and Gould's sand goanna (Varanus gouldii) within three large Australian properties differing in their level of grazing-induced degradation. Some paddocks had a long history of overgrazing by domestic livestock (termed 'Pastoral'), while others had been dedicated to the conservation of reintroduced native, soil disturbing animals ('Conservation'). A number of adjoining paddocks had been destocked in 2000, and were therefore recovering from grazing ('Recovering'). The pastoral land use is the predominant management type across much of semi-arid Australia.

Within each level of grazing we measured animal disturbances (pit width, depth and length) under two common patch types (trees and shrubs) and compared them with the interspaces. For trees and shrubs we also recorded their relative position within the canopy i.e. at the trunk, mid-canopy, canopy edge. Foraging pit measurements were made along 2-meter wide transects extending out from the tree or shrub trunk. The length of each transect was three-times the radius of the canopy. We used allometric data on the relationship between pit width, depth and length, and soil mass from a previous study (D. Eldridge unpublished data) to estimate the mass of soil removed from each pit. The simple product of foraging pit width, length and depth was most closely (and linearly) related to soil mass (soil mass [tonnes] $=0.000373 \times$ artificial volume $\mathrm{cm}^{3}+0.67 ; F_{1,91}=405.7, P<0.001, R^{2}=0.81$ ).

Differences in foraging pit density, volume and mass of soil removed were examined using Mixed-Models ANOVAs with multiple error terms. Data were transformed prior to ANOVA, where necessary, based on diagnostic tests (e.g. residual and normal plots) (Payne et al., 

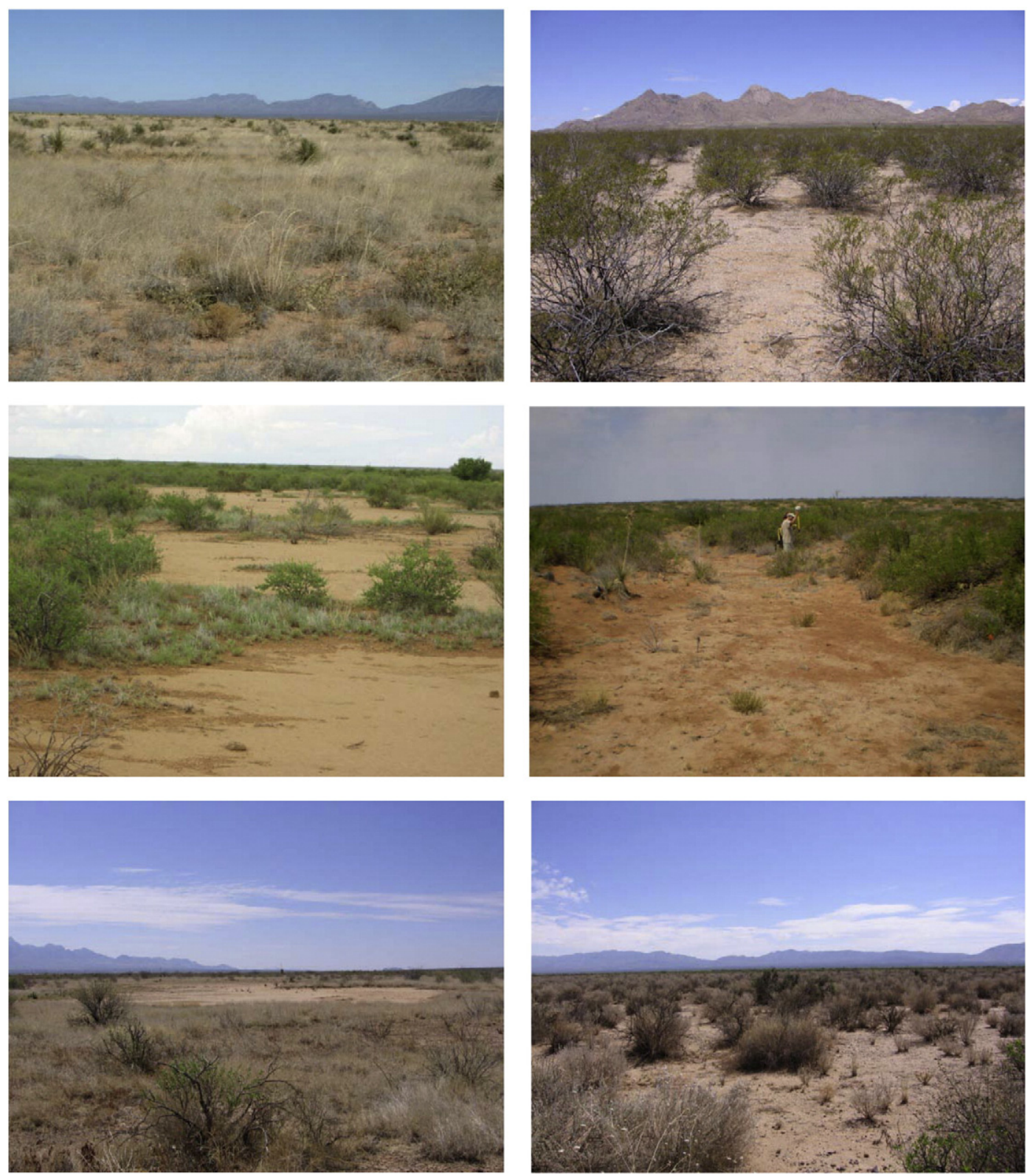

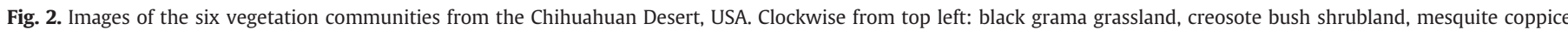
dunefield, tarbush swale, tobosa grass playa and banded playa. Photographs: Jane Smith.

1993). Significant differences between means were examined using Fisher's Protected Least Significant Difference (LSD) testing.

\subsection{Soil movement in relation to vegetation community in the Australian semi-arid woodlands}

We examined soil disturbance by the short-beaked echidna, sand goanna, burrowing bettong (Bettongia leuseur) and greater bilby (Macrotis lagotis) in four plant communities within a large $\left(36 \mathrm{~km}^{2}\right)$ paddock under the 'Conservation' treatment. The density and size (width, length, depth) of foraging pits were assessed at 11 times over a 30-month period (three-monthly; December 2007 to July 2010) along $36,200 \mathrm{~m}^{2}$ (50 $\mathrm{m}$ long by $4 \mathrm{~m}$ wide) transects. There were eight sites from each of four communities listed in Section 2.1. Pits constructed by the burrowing bettong and the greater bilby were pooled because they cannot readily be distinguished due to similar morphologies. Turnover rates $\left(\% \mathrm{yr}^{-1}\right)$ were calculated as the average of new pit appearances and disappearances (considered over the 30 months but expressed as a percentage per year), and divided by the average of the initial and final densities per transect.

Similar mixed-models ANOVAs were used to examine differences in pit density among vegetation communities, time and their interaction. The Greenhouse-Geiser correction was used to account for possible autocorrelation between the seven time periods. Bettongs and bilbies were introduced 18 months after the study commenced, so the degrees of freedom for the analyses were reduced. Data were transformed, where necessary and LSD used to separate means based on significant F-statistics (see above).

\subsection{Soil movement in Chihuahuan desert grasslands and shrublands}

Data were collected on the density of foraging pits constructed by heteromyid rodent (particularly Dipodomys spectabilis), skunks (Mephitis spp.), pocket gophers (Thamomys bottae, Geomys bursarius) and ground squirrels (Spermophilis spilosoma) in an arid shrubland in the northern Chihuahuan Desert between 1999 and 2001. Disturbances were studied in the six vegetation communities described in Section 2.1 
above. Data were collected from three replicate 1 ha $(100 \times 100 \mathrm{~m})$ plots in each vegetation community in summer 1999, and summer, autumn, winter and spring in 2000 and 2001. In 1999 and 2000 we examined disturbances in $10 \times 10 \mathrm{~m}$ quadrats located at each corner of each 1 ha site. In 2001 we sampled a larger area of each community by using $10 \mathrm{~m}$ radius circular plots located at three of the corners of each 1 ha site. Pits were measured (depth, width, length), assigned to a particular animal (if known), and their volume calculated (using the formula for a prolate sphere). Soil mass was calculated using a conservative estimate of $0.8 \mathrm{Mg} \mathrm{m}^{-3}$ soil.

Data for each of the three years were pooled into three seasons that corresponded with periods of high or low animal activity i.e. cool season (November to April), warm-dry season (May to June), and warm-wet season (July to October). This had the effect of collapsing our data into seven year-season combinations i.e. warm-dry season $(1999,2000,2001)$, cool season $(2000,2001)$, and warm-wet season (2000, 2001). Our analyses employed a Mixed-Models ANOVA approach with multiple error terms considering differences among the six communities, the seven year-season effects, and the interactions with community type (Payne et al., 1993), after applying the usual diagnostic tests described above. Where some communities had no data for that variable (e.g. where relatively few structures were found in that community), the number of communities was reduced in the analyses. Least Significant Difference testing was used to examine differences between mean values. Bonferroni corrections were made when comparing means among a large number of multiple comparisons arising from the six vegetation communities or seven year-seasons.

\subsection{Location and infilling rates of heteromyid rodent pits}

One of the three replicate sites was chosen in five of the six communities described in Section 2.4 (except Banded playa) to examine foraging pit formation in relation to patch type. At each site we recorded the distance to the nearest perennial plant of the first 30 heteromyid pits encountered along a $2.5 \mathrm{~m}$-wide transect of variable length.

Along the same transects we constructed 30 artificial heteromyid rodent pits ( $8 \mathrm{~cm}$ wide by $3 \mathrm{~cm}$ deep). Ten pits were under perennial plant canopies, 10 in the middle of the interspaces, and 10 between these pits and the plant canopies. Rates of infilling (monthly changes in depth) were measured over a 19 week period using erosion pits. We used two-way ANOVA to examine differences in infilling rates in relation to distance from the plant and vegetation community (and their interaction) after applying the usual diagnostic tests described above.

\subsection{Heteromyid rodent pits: surface stability, labile carbon and infiltration} rates

Soil aggregate stability was measured in randomly selected heteromyid rodent cache pits and surface soils adjacent to grass canopies and in the interspaces $(n=12)$ with a modified wet sieving technique (Herrick et al., 2001). Differences in aggregate stability were assessed in relation to location (pit, surface), microsite (canopy, interspace) and their interaction using General Linear Models (Payne et al., 1993). Labile carbon was measured on soils from 10 pits and adjacent non-pit surfaces taken along the same $2.5 \mathrm{~m}$ wide transects using a simplified $\mathrm{KMnO}_{4}$ reduction technique (Weil et al., 2003). We used a single-ring infiltrometer to measure water infiltration on pits and adjacent undisturbed soil within four of the vegetation communities; 11 pits in the creosote bush shrubland (gravelly sand surface texture), six in black grama grassland (sandy clay loam to sandy loam), 10 in tobosa grasslands (silty loam), and six in tarbush shrubland (loam to clay loam). We selected the maximum number of pits at each site that we could find of a similar age (i.e. about 3 months old). Measurements could not be made at the other Chihuahuan Desert sites due to logistical constraints. Nevertheless, the four sites enabled us to test whether the effects of pits on infiltration were moderated by soil texture. Differences
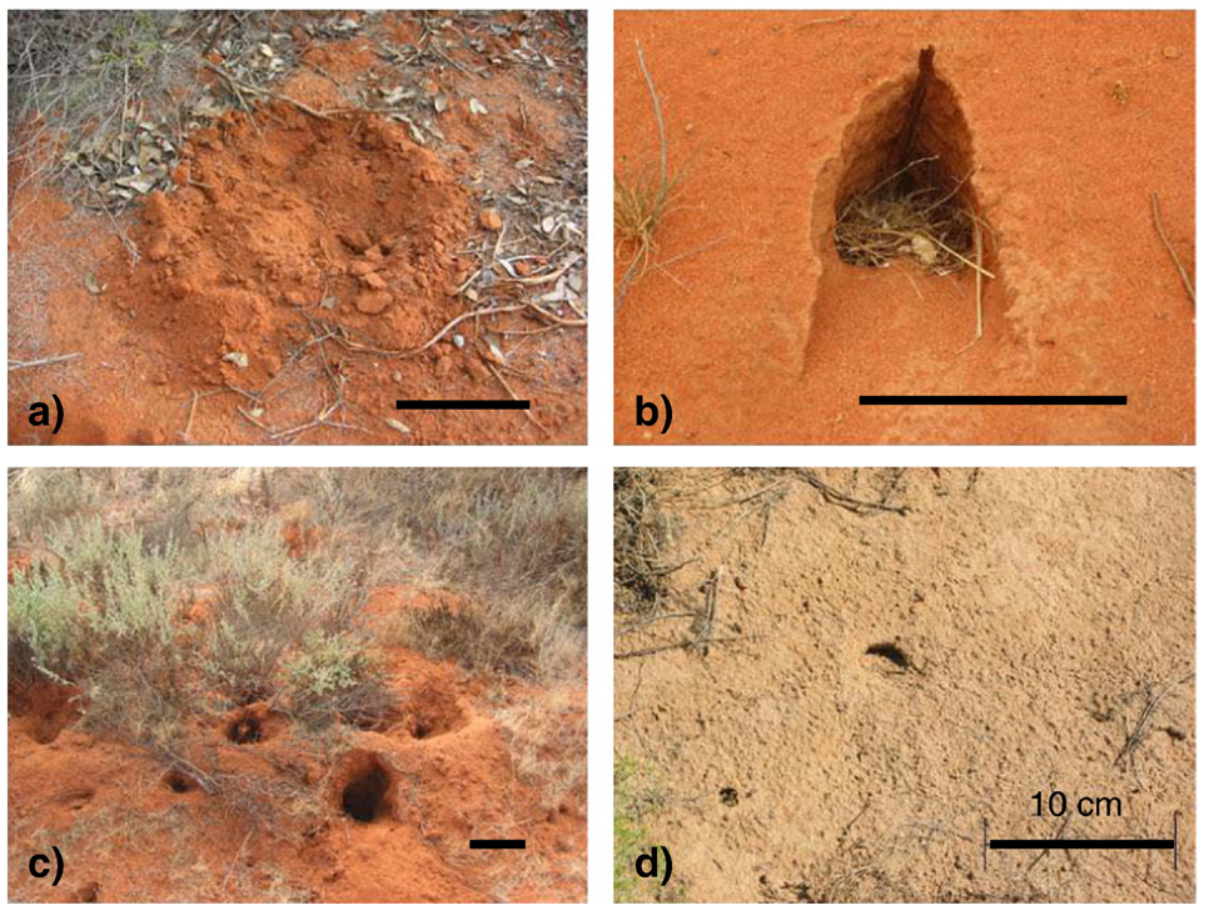

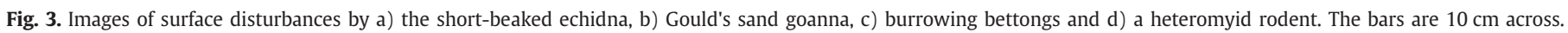
Photographs: David Eldridge. 
in labile carbon and infiltration in relation to pits and surface were examined using two-way ANOVA.

\section{Results}

\subsection{Foraging pit size and shape}

Foraging pits of all soil-disturbing vertebrates were morphologically distinct. These differences would therefore be expected to affect resource capture and retention and therefore the functional significance of the disturbances. Foraging by echidnas creates a number of different disturbance types ranging from shallow nose pokes, to deeper foraging pits, and extensive tracts of bull-dozing (Rismiller, 1999). Typically, echidna foraging pits are circular-shaped, about $15-25 \mathrm{~cm}$ in diameter, $5-15 \mathrm{~cm}$ deep, and surrounded by a loose collection of large soil clods (Eldridge and Mensinga, 2007; Fig. 3a). In sandy soils, material ejected from the pits is relatively poorly-aggregated, but material in loamy soils tends to be cloddy and highly aggregated. Goanna foraging pits are typically narrow, elliptical-shaped pits excavated at an angle of about $40^{\circ}$ to the soil surface. They are sometimes wedge-shaped, and characterized by shallow, v-shaped grooves along either side of the base where the soil had been excavated by the reptiles' strong forelimbs (Eldridge and Kwok, 2008). As goannas prey heavily on epigeal spiders (e.g. Lycosidae and Gnaphosidae families), the pits often track vertically along the spider burrows (Fig. 3b).

Bettong (and bilby) foraging pits ranged from cylindrical-shaped excavations $15 \mathrm{~cm}$ wide by $10-20 \mathrm{~cm}$ deep to shallow surface depression similar to echidna pits (Fig. 3c). Unlike echidna pits, however, the ejecta is concentrated at one side of the pit. Bettong pits tend to be slightly deeper (up to $20 \mathrm{~cm}$ deep) in sandy soils due to the greater ease of digging. Cache and foraging pits of Heteromyid rodents, skunks and ground squirrels average about $8 \mathrm{~cm}$ wide and $3 \mathrm{~cm}$ deep. Overall, bettong/bilby $\left(0.0099 \mathrm{~m}^{3}\right)$ and echidna $\left(0.0096 \mathrm{~m}^{3}\right)$ pits are similar in volume and about $70 \%$ larger than goanna pits $\left(0.0058 \mathrm{~m}^{3}\right)$. Heteromyid rodent pits
(Fig. 3d) are generally an order of magnitude smaller than those of the soil foraging Australian vertebrates $\left(0.000175 \mathrm{~m}^{3}\right)$.

\subsection{Soil movement in relation to grazing}

We detected substantial differences in soil foraging by echidnas and goannas across the three Australian land management types. Density of soil disturbances was greatest where grazing by domestic livestock was excluded (Conservation) and least at sites grazed by sheep and cattle (Pastoral: $F_{2,54}=99.85, P<0.001$; Table 2 ). This equated to a ten-fold greater soil excavation by goannas and echidnas under the conservation management $\left(F_{2,54}=159.6, P<0.001\right)$. Cover of disturbed soil followed a similar trend $\left(F_{2,54}=132.16, P<0.001\right)$. Interestingly, the volume of echidna pits tended to be three- to five-times greater (volume: $2962 \pm 257 \mathrm{~cm}^{3}$; mean $\pm \mathrm{SE}$ ) under the Pastoral treatment than either Conservation $\left(903 \pm 393 \mathrm{~cm}^{3}\right)$ or Recovering $\left(618 \pm 108 \mathrm{~cm}^{3}\right)$ treatments (Huang, 2007).

\subsection{Soil movement in relation to plant communities}

Echidnas tended to excavate about 2.5-times more soil in the swales and cleared woodlands $\left(1.86 \pm 0.138 \mathrm{tha}^{-1}\right)$ where shrub cover was substantially greater, than the dunes and intact woodlands $\left(0.73 \pm 0.056 \mathrm{t} \mathrm{ha}^{-1}, F_{3,24}=3.55, P=0.029\right)$. This trend was consistent among all time periods (Community by Time interaction: $P=0.52$; Fig. 4a). Soil excavation by goannas in intact woodland $(0.222 \pm$ $0.016 \mathrm{tha}^{-1}$ ) was substantially less than that in the other communities $\left(0.617 \pm 0.042 \mathrm{tha}^{-1} ; F_{3,24}=3.40, P=0.034\right.$; Fig. 4b). There was considerable temporal variation in soil excavation by bettongs/bilbies, particularly in the dunes $\left(F_{6,192}=35.3, P<0.001\right)$, but no general difference among communities $(P=0.62$; Fig. $4 c)$.

For Chihuahuan Desert heteromyid rodents, there were significantly more pits in the black grama grassland, creosote bush shrubland and mesquite dunefields (range: 627-795 pits ha ${ }^{-1}$ ) than in the tarbush shrubland, and tobosa grass and banded grasslands (192-212 pits ha ${ }^{-1}$;

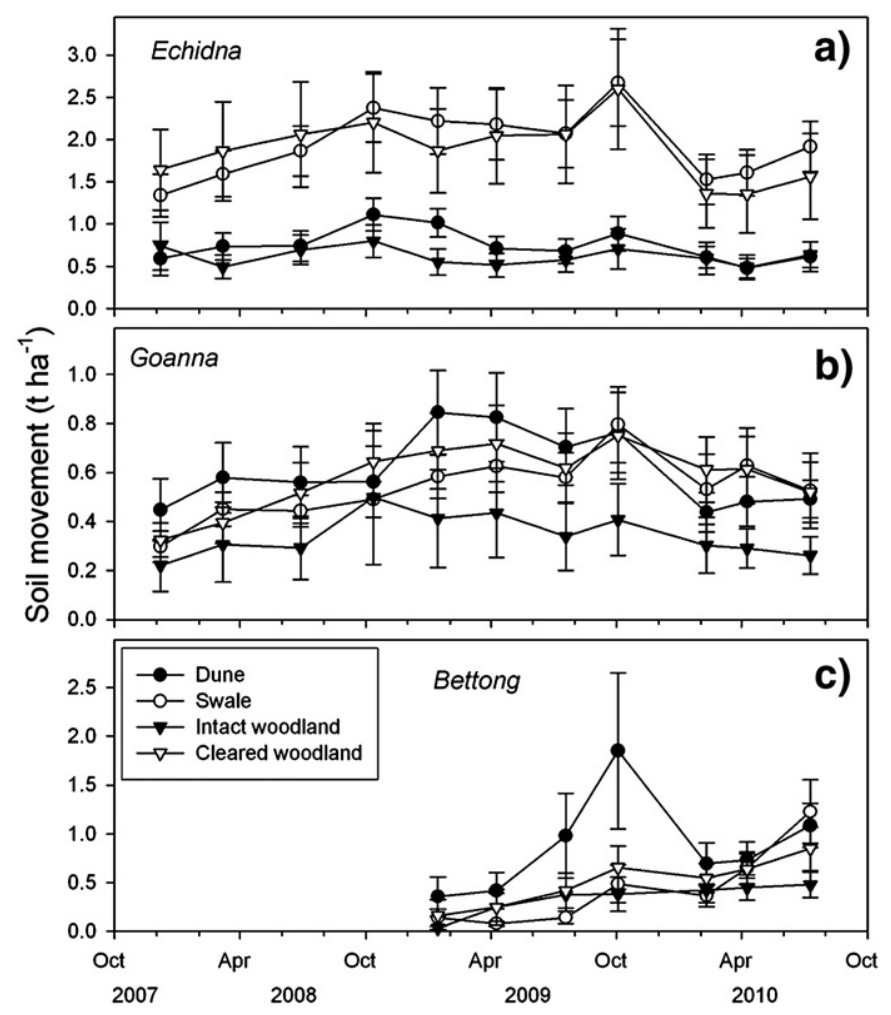

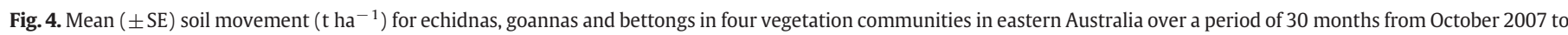
July 2010. 

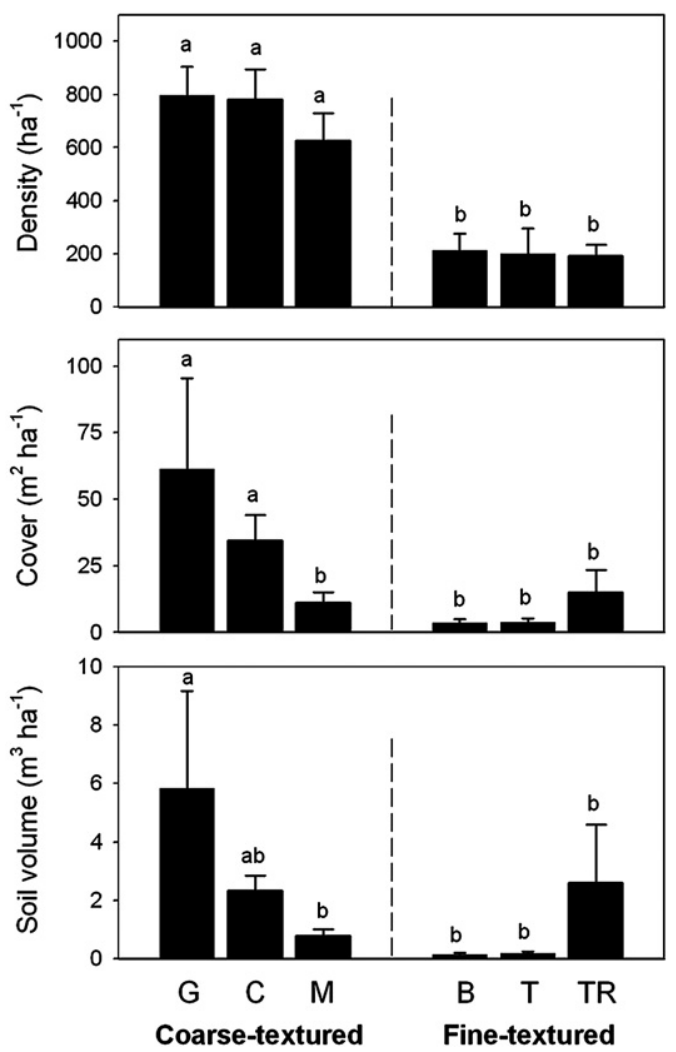

Fig. 5. Mean $( \pm \mathrm{SE})$ density ( pits ha $\left.^{-1}\right)$, cover $\left(\mathrm{m}^{2} \mathrm{ha}^{-1}\right)$ and volume of soil excavated $\left(\mathrm{m}^{3} \mathrm{ha}^{-1}\right)$ in relation to vegetation community, organized by soil texture for the six communities in the Chihuahuan Desert. $\mathrm{G}=$ black grama grassland, $\mathrm{C}=$ creosote bush shrubland, $\mathrm{M}=$ mesquite coppice dunefield, $\mathrm{B}=$ banded playa, $\mathrm{T}=$ tabosa grass playa, $\mathrm{TR}=$ tarbush shrubland. Different letters indicate a significant difference in the attributes at $P<0.05$.

$F_{5,10}=22.35, P<0.001$, averaged across all years and seasons; Fig. 5). Cover of disturbances was also greatest in the black grama grasslands $\left(61 \mathrm{~m}^{2} \mathrm{ha}^{-1}\right)$ than the other communities $\left(4-15 \mathrm{~m}^{2} \mathrm{ha}^{-1} ; F_{5,10}=4.12\right.$, $P<0.027)$. The volumes of soil excavated were also greatest in the black grama grasslands $\left(5.83 \mathrm{~m}^{3} \mathrm{ha}^{-1}\right)$ than the other communities $(0.14-$ $2.6 \mathrm{~m}^{3} \mathrm{ha}^{-1} ; F_{5,10}=4.17, P<0.026$; Fig. 5 ).

For the Australian vertebrates, the mass of soil moved during foraging varied markedly over the 30 -month period (bettong/bilby: $F_{6,192}=35.3$, $P<0.001$; echidna: $F_{10,320}=6.47, P<0.001$; goanna: $F_{10,320}=12.8$, $P<0.001$; Fig. 4a to c). This temporal variability was also reflected in the data for pit turnover, which was relatively high in the dunes $\left(15.7 \% \mathrm{yr}^{-1}\right)$ compared with the other communities $\left(8.2-10.3 \% \mathrm{yr}^{-1} ; F_{3,32}=9.45\right.$, $P<0.001)$. There were also marked temporal changes in the density, cover and volume of soil moved in the pits of heteromyid rodents and other

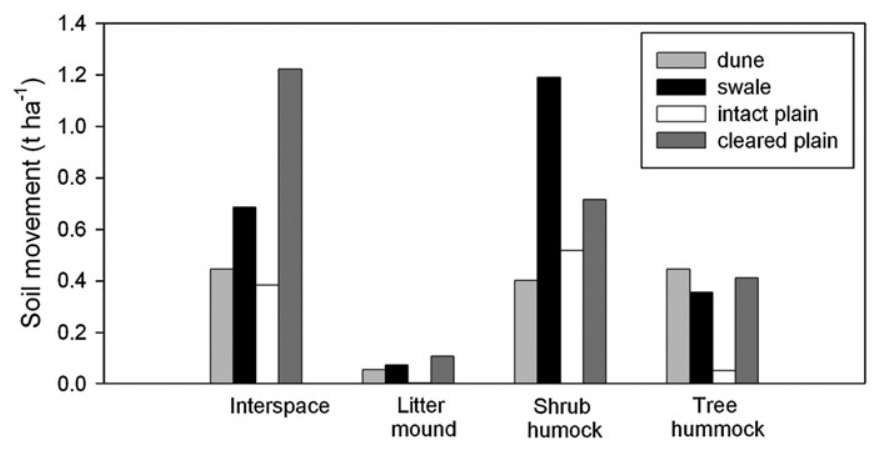

Fig. 6. Soil movement $\left(\mathrm{tha}^{-1}\right)$ by echidnas and goannas in the four vegetation communities in eastern Australia in relation to the four patch types.

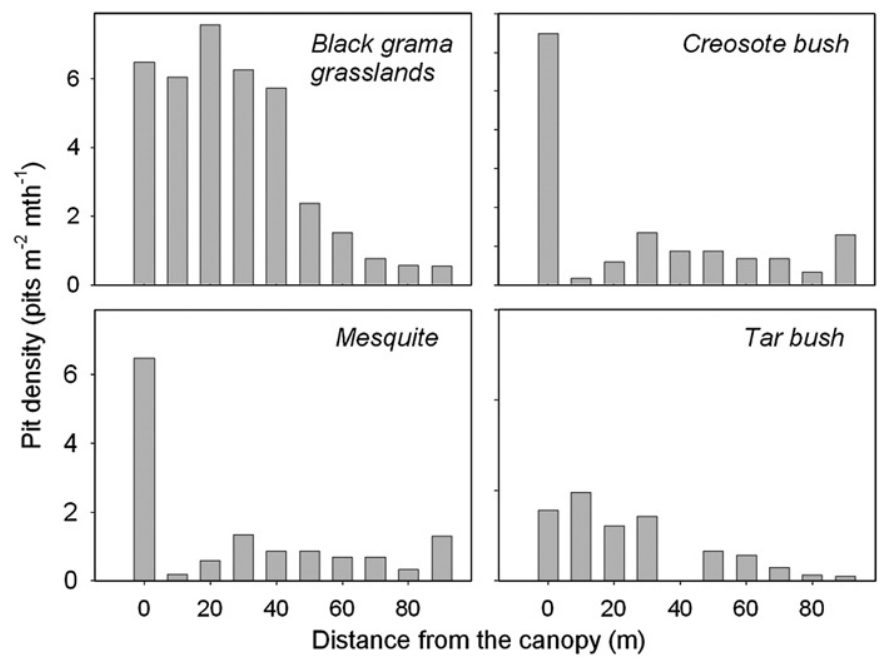

Fig. 7. Distribution of foraging pits in relation to grass tussocks and shrub canopies in the black grama grasslands, creosote bush, mesquite and tar bush shrublands in the Chihuahuan Desert.

small mammals. In particular, the volume of excavated pit soil was greatest in the Warm-Dry period in $1999\left(10.6 \mathrm{~m}^{3} \mathrm{ha}^{-1}\right)$ compared with other periods $\left(0.24-0.84 \mathrm{~m}^{3} \mathrm{ha}^{-1} ; P<0.001\right)$. Some of this variability can be accounted for by rainfall in the 3 months preceding measurements in May $2000\left(F_{1,16}=7.35, P=0.015, R^{2}=0.27\right)$ and October-November $2000\left(F_{1,16}=8.31, P=0.011, R^{2}=0.30\right)$, but there were no significant relationships for any other periods.

\subsection{Soil movement in relation to patch types}

For the Australian vertebrates, the cover of disturbances under trees tended to be greatest at the canopy edge than close to the trunk $(P=0.003)$. For shrubs, however, significantly more disturbances were found at mid-canopy locations (Macro-patch type $\times$ Patch location interaction: $\left.F_{3,324}=2.65, P=0.049\right)$. While foraging was generally centered under trees in the Conservation and Recovering land uses, it was greatest under shrubs in the Pastoral treatment (Treatment $\times$ Macro-patch type interaction: $\left.F_{2,54}=3.59, P=0.034\right)$.

For the 30-month Australian longitudinal study, the mass of soil excavated among the four different patches (interspace, litter mound, shrub hummock, tree hummock) varied among the four vegetation communities (chi squared $=1320$, $d f=9, P<0.001$ ). In general, most soil in the cleared plains came from the interspaces, while in the swales, most soil was removed from the shrub hummocks (Fig. 6). This may be a reflection more of the relative availability of different patch types than any preference for different patches per se.

Disturbances by heteromyid rodents and other small mammals in the Chihuahuan Desert also tended to be concentrated around perennial plants, though this varied with vegetation community. For example, most disturbances were within $60 \mathrm{~cm}$ of a grass tussock in the black grama grasslands, or under shrub canopies in shrub-dominated mesquite and creosote bush sites (Fig. 7). In tarbush shrublands and tobosa grasslands, however, disturbances were relatively evenly distributed in relation to vegetation patches and interspaces (Fig. 7). About $60 \%$ of all diggings in the black grama grasslands (14.1 kg soil $\mathrm{m}^{-2} \mathrm{yr}^{-1}$ ) were within $0.5 \mathrm{~m}$ of grass tussocks. Rodents therefore disturbed large amounts of soil under shrub canopies in the creosote bush $\left(7.9 \mathrm{~kg}\right.$ soil m $\left.\mathrm{mr}^{-2} \mathrm{yr}^{-1}\right)$ and mesquite $\left(2.62 \mathrm{~kg} \mathrm{soil} \mathrm{m}^{-2} \mathrm{yr}^{-1}\right.$ ) shrublands. Artificially-excavated rodent foraging pits infilled at a rate of about $5.7 \mathrm{~mm}^{\text {month }}{ }^{-1}$. This rate did not vary among vegetation communities $(P<0.05)$, with distance from the nearest perennial plant $(P>0.10)$, nor in relation to the size (depth or opening diameter) of the pit $(P=0.20)$. 

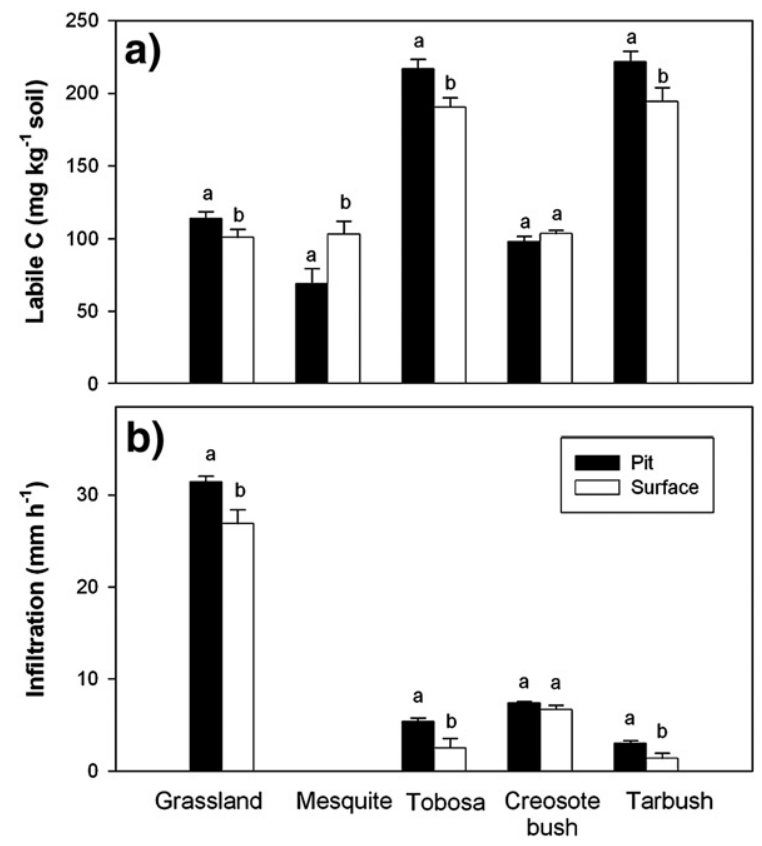

Fig. 8. Mean $( \pm \mathrm{SE})$ values for (a) labile $C\left(\mathrm{mg} \mathrm{C} \mathrm{kg}^{-1}\right.$ soil) and (b) infiltration $\left(\mathrm{mm} \mathrm{h}^{-1}\right)$ from foraging pit and non-pit surfaces within five of the six vegetation communities in the Chihuahuan Desert. Different letters within a community indicate a significant difference at $P<0.05$.

\subsection{Effects of soil movement on soil processes}

Aggregate stability tended to be significantly lower in Heteromyid rodent pits than the surface in the tarbush shrubland $(P=0.02)$ and tobosa $(P=0.027)$ and black-grama grasslands $(P=0.020)$, but not in the other communities $(P>0.05)$. Labile carbon ranged from about $100-200 \mathrm{mg} \mathrm{C} \mathrm{kg}^{-1}$ soil, and was significantly greater in the rodent pits in the black grama $\left(F_{1,29}=4.42, P=0.044\right)$ and tobosa $\left(F_{1,23}=8.26\right.$, $P=0.009)$ grasslands and tarbush shrublands $\left(F_{1,12}=7.08, P=0.021\right)$ than in surface soils, but lower in the pits in the mesquite dunefields $\left(F_{1,23}=10.21, P=0.004\right)$. There were no significant differences, however, in the creosote bush shrublands ( $P=0.29$; Fig. 8a). Infiltration was significantly greater through pits than adjacent non-pit surfaces in the tobosa $\left(F_{1,9}=11.12, P=0.009\right)$ and black-grama $\left(F_{1,5}=7.76\right.$, $P=0.039)$ grasslands, and tarbush shrublands $\left(F_{1,5}=12.04\right.$, $P=0.018)$, but not the creosote bush shrublands $(P=0.47)$ (Fig. $8 b$ ).

\section{Discussion}

Soil disturbance by animals has long been recognized as an important element in soil formation (Darwin, 1881). Animals are important components of arid and semi-arid ecosystems and have farreaching effects on ecosystem processes and properties (Chew, 1979; Whitford and Kay, 1999; Whitford, 2002). Our study compared the extent of surface disturbance by soil-foraging animals in two markedly different environments; the semi-arid woodlands of eastern Australia, and an arid desert grassland-shrubland ecosystem in the Northern Chihuahuan Desert, USA. Six important trends emerged from our study. Firstly, the structures created by animals differed markedly among animal species, and were scaled approximately to their body size. This suggests that different-sized animals, and therefore different sized surface disturbances, are likely to have differential effects on the retention and/or loss of resources from these systems. Secondly, animals disturbed substantial volumes of soil in both environments, suggesting that they should be considered important agents of geomorphological processes in these arid and semi-arid environments. Thirdly, digging was both spatially and temporally variable, with pit size and density differing in relation to land use (i.e. grazed, recovering or conservation), reinforcing our view that any effects of disturbance will not be uniform across the landscape or among different seasons. Fourthly, foraging, and hence pit construction in both environments were generally greater (though not exclusively) in areas with dense stands of shrubs. Fifthly, foraging, and therefore soil movement, were generally concentrated close to the edge of perennial plants such as around the tussocks of grasses and tree canopies, and sixthly, while the gross effects of foraging on soil processes were generally consistent within both environments, there were small differences among the vegetation communities in the magnitude of the effects.

\subsection{Comparison of soil movement among different vertebrates}

A number of authors have provided extensive commentaries of the effects of animals on soils and soil processes (e.g. Hole, 1981; Viles, 1988; Butler, 1995), and recent reviews emphasize their particular importance in arid landscapes (Whitford and Kay, 1999). Our studies demonstrate rates of soil removal of up to $3 \mathrm{t} \mathrm{ha}^{-1}$ for medium-sized vertebrates in eastern Australia, and up to $7.2 \mathrm{t} \mathrm{ha}^{-1}$ (assuming a conservative estimate of bulk density of $1.2 \mathrm{Mg} \mathrm{m}^{-3}$ ) for heteromyid rodents in the Chihuahuan Desert. Data on soil movement for arid areas worldwide are, however, highly variable. Relatively low rates of removal $\left(<0.5 \mathrm{tha}^{-1}\right)$ have been reported for the foraging pits and diggings of Gould's sand goanna, the short-beaked echidna, the European rabbit (Oryctolagus cuniculus) and various kangaroo (Macropus) species in eastern Australia (Wood, 1985; Robinson, 2003; Huang, 2007; James and Eldridge, 2007; Eldridge and Kwok, 2008), the Louisiana pocket gopher (Geomys breviceps), the lesser Egyptian jerboa (Jaculus jaculus) and Wagner's gerbil (Gerbillus dasyurus) in semi-arid woodland, shrubland and steppe in the Middle East (Hatough-Bouran, 1990), Russia (Ognev, 1947) and the United States (Buechner, 1942). Moderate rates of $30-100 \mathrm{t} \mathrm{ha}^{-1}$ have been reported, mainly in the mounds and foraging complexes of the European rabbit from Australia (29-88 $\mathrm{t} \mathrm{ha}^{-1}$, Eldridge and James, 2009), the mounds of hairy-nosed wombat (Lasiorhinus latifrons; $88 \mathrm{t} \mathrm{ha}^{-1}$, Steele and Temple-Smith, 1998) and pocket gophers (Thamomys talpoides) in arid shrubland in the United States ( $88 \mathrm{t} \mathrm{ha}^{-1}$, Richens, 1966). Rates of $188-450 \mathrm{t} \mathrm{ha}^{-1}$ have been reported from the mounds of various marmots (Marmota bobak, Marmota caudata) in the Russian steppe (Ognev, 1947; Zimina et al., 1970; Zimina and Zlotin, 1980). Rates of soil removal reported by Whitford and Kay (1999) in their review of fossorial animals ranged from $2.3 \times 10^{-6} \mathrm{~m}^{3}$ for heteromyid rodents in the Chihuahuan Desert (Steinberger and Whitford, 1983) to $1390 \mathrm{~m}^{3}$ for the tuco tuco (Ctenomys azarae) in Argentina (Roig et al., 1988). While these values do not equate with actual soil production rates and do not take into account per capita pit construction by the various animals nor the bulk density of soils, they nevertheless indicate that soil movement by animals in deserts is substantial.

\subsection{Foraging is concentrated in shrublands and close to perennial plants}

Our data from both continents show some interesting trends in relation to the effects of woody plants on animal foraging and soil removal. Encroachment of grassland by shrubland in the Chihuahuan Desert was associated with no significant change in the density of heteromyid foraging pits, but a five-fold decline in cover, and a six-fold decline in the volume, of soil removed from grassland compared with mesquite shrubland (Fig. 4). However, this trend was only evident on coarse-textured soils, with no effects on finer soils, indicating a moderating effect of soil texture. While the construction of pits in shrublands may enhance the downslope transport of sediment (Sherrod and Seastedt, 2001), it may be an essential process in grasslands for covering litter and promoting the mineralization of organic matter. Increases in shrub density are known to be associated with declines in populations of rodents such as the banner-tailed kangaroo rat (D. spectabilis), which requires perennial grasses to lactate (Soholt, 1977). The soil-disturbing activities of kangaroo rats may also enhance 
penetration of the roots of some shrubs through hardpans of caliche allowing them to reach the watertable (Gile et al., 1981). The landscapelevel effects of caliche penetration can be an increase in the deposition of $\mathrm{N}$ and $\mathrm{P}$, which originates via the surface weathering of caliche (Eghbal and Southard, 1993a, 1993b). Indeed, the large burrow systems of rats have been shown to enhance the density of shrubs such as creosote bush, reinforcing the shrub-encroached state long after the loss of rats from shrublands (Eldridge et al., 2009).

In Australia, soil removal was substantially greater in areas where trees had been removed and which supported an extensive area of shrub regrowth. We recorded rates of $1.5-2 \mathrm{t} \mathrm{ha}^{-1}$ (short-beaked echidnas) and $0.5 \mathrm{t} \mathrm{ha}^{-1}$ (Gould's sand goannas) in cleared woodland compared with 0.5 and $0.2 \mathrm{t} \mathrm{ha}^{-1}$ for echidnas and goannas, respectively, in intact woodlands. Differences in digging activity probably relate to substantially greater (five-fold) cover and density of Maireana, Senna and Eremophila shrubs that provide both habitat and forage resources in the cleared woodland. Cleared woodlands also provide extensive habitat, in the form of fallen timber and down logs, which have been shown to increase the density of small mammals in arid systems. Together then, a consistent trend to emerge from the two studies across both continents is the importance of shrubs as foraging sites for ground-foraging vertebrates.

Our study reinforces the notion that foraging by animals, and therefore the distribution of their foraging pits and ejecta soil, is not uniform, either among or within vegetation communities. We showed that foraging in the Chihuahuan Desert tended to be concentrated near the canopies of perennial plants (Fig. 7), while shrub hummocks in the semi-arid woodlands of Australia tended to support a high density of pits (though only in the swales; Fig. 6). Preference for perennial plant patches among different vegetation communities may explain why annual plants tend to be concentrated under the canopies of shrubs in some landscapes but not others. For example, caching by kangaroo rats (Dipodomys spp.) in mesquite coppice dunefields and creosote bush shrubland is almost exclusively under the canopy, contrasting with a more even distribution of seed caches in the black grama grassland (Duval et al., 2005, Fig. 6). Similarly, in Australia, foraging pits of the Tasmanian bettong (Bettongia gaimardi) are known to be concentrated around the tree trunks, where hypogeal fungi, substantial food sources, are concentrated (Johnson, 1994). Taken together, the preferential excavation of pits under the canopies of perennial plants in some landscapes would be expected to reinforce the 'fertile island' effect that exists under many arid zone shrubs (e.g. De Villiers et al., 2001). The capture of the seeds of community-dominant species, suggest to us that pits contribute to the maintenance of ecosystem inertia by reinforcing the germination of existing community dominants within either natural or altered communities.

\subsection{Effects of animal disturbances and digging on soil processes}

We demonstrated in our two systems that animals had substantial effects on soil movement and soil turnover, with areal rates of about $3 \mathrm{tha}^{-1}$ for semi-arid Australian woodlands and up to $141 \mathrm{~m}^{3}$ (per hectare of plant canopy) for Chihuahuan Desert grasslands and shrublands. These rates of soil movement are highly temporally (Fig. 4) and spatially variable, and our data indicate a moderating effect of landuse,

\section{Table 2}

Mean $\left( \pm\right.$ SE) density (foraging pits ha $\left.{ }^{-1}\right)$, volume $\left(\mathrm{cm}^{3}\right.$ per disturbance) and mass of soil $\left(\mathrm{t} \mathrm{ha}^{-1}\right)$ for echidnas and goannas across the three treatments in eastern Australia. Different subscripts with a row indicate a significant difference at $P<0.05$.

\begin{tabular}{|c|c|c|c|c|c|c|}
\hline \multirow[t]{2}{*}{ Animal } & \multicolumn{2}{|c|}{ Conservation } & \multicolumn{2}{|c|}{ Recovering } & \multicolumn{2}{|l|}{ Pastoral } \\
\hline & Mean & SEM & Mean & SEM & Mean & SEM \\
\hline Pit density $\left(\mathrm{ha}^{-1}\right)$ & $17,695^{\mathrm{a}}$ & 2006 & $5265^{b}$ & 883 & $956^{c}$ & 471 \\
\hline Pit volume $\left(\mathrm{cm}^{3}\right)$ & $1811^{\mathrm{a}}$ & 874 & $1611^{\mathrm{a}}$ & 451 & $2530^{\mathrm{b}}$ & 445 \\
\hline Mass soil $\left(\mathrm{t} \mathrm{ha}^{-1}\right)$ & $32.0^{\mathrm{a}}$ & 1.3 & $6.4^{\mathrm{b}}$ & 0.2 & $3.1^{\mathrm{b}}$ & 0.2 \\
\hline
\end{tabular}

particularly grazing, on these rates (Table 2). Overgrazing of semi-arid woodland in eastern Australia reduces plant cover and vegetation structure, ultimately reducing habitat quality for ground-foraging animals such as the short-beaked echidna. Foraging pits in grazed (pastoral) areas were substantially larger, suggesting to us that echidnas may be foraging more on termites than ants (Abensperg-Truan, 1991), a commonly observed phenomenon in areas of extensive resource-depletion. The effect of overgrazing, therefore, is to 1) concentrate pits under perennial plant canopies, 2) reduce the per-capita creation of echidna pits, and 3) reduce the mass of soil removed at landscape scales. Any reductions in historic soil movement levels are likely to affect other ecosystem processes such as horizon development or the movement of clay-rich sediment to lower landscape positions. In overgrazed areas, for example, the consequences of fewer, deeper pits may be an increase in sites for capture of litter and sediment mobilized by animal trampling, given that there will be less vegetation available for resource capture. Thus while the combined activities of soil-disturbing animals are likely to lead to the development of soil biomantles, this is likely to be moderated by differences in grazing rates.

Notwithstanding any effects at small spatial scales i.e. pit versus nonpit surface, there are also likely to be landscape-scale effects. For example, soil movement by gophers while excavating their tunnels has been shown to lead to the concentration of stone layers that are too large for the gophers to move (Johnson, 1994). Similarly, large communal mound structures built by hairy-nosed wombats, bilbies and the European rabbit (Eldridge and James, 2009) provide habitat for a wide range of vertebrates and invertebrates (e.g. Read et al., 2008). Changes in soil chemistry in these structures, particularly increases in the C:N ratio, a consequence of the translocation of $\mathrm{N}$-poor subsoil to the surface, may be a mechanism to allow the reestablishment of indigenous plant species at the expense of nitrophilous exotic species (Eldridge and Whitford, 2009).

\subsection{Animal foraging pits and disturbances as resource traps}

The consequences of animal disturbance are also likely to differ among different animals, mainly through variation in two attributes, 1) pit morphology, and 2) per-capita production of pits. Both attributes determine the capture and subsequent retention of resources. Pits constructed in coarse-textured soils such as those of the mesquite coppice dunefields in the Chihuahuan Desert or the mallee dunefields in eastern Australia have relatively high turnover rates due to both a high rate of pit creation, and an extremely low structural integrity. Typical heteromyid rodent pits in the Chihuahuan Desert (100-300 $\mathrm{cm}^{3}$ ) infill after about 5.7 months. Turnover is likely to be greater where pits are not reopened by animals in search of cached seeds. Small pits with very few seeds often go largely undetected by rodents after caching, and the ability of rodents such as kangaroo rats to collect food decreases dramatically as soils become coarser (Randall, 1993; Geluso, 2005). Thus only a small proportion of cache pits in coarse-textured soils are ever relocated and reopened by rodents (Geluso, 2005). Further, decomposition is known to be greater in pits containing a smaller mass of litter than those with larger amounts of litter (Urbaniak and Whitford, 1983), possible because of the larger surface area over which the material is subjected to microbial breakdown.

Extensive research worldwide indicates that animal-created structures capture greater quantities of seed and support more plant species than adjacent non-pit surfaces (e.g. Boeken et al., 1995; James and Eldridge, 2007; James et al., 2009). Pits may contain seed that has been intentionally cached by rodents (Duval et al., 2005; Geluso, 2005), seed accumulating through the action of wind and water (James and Eldridge, 2007), or both. Our study demonstrated significantly greater levels of water infiltration and labile carbon in the pits in the tarbush shrublands and black grama and tobosa grasslands. Thus one of the functions of foraging disturbances is to bring together nutrients and 
water with pit-resident seed, maximizing the chances of an ecological response (Eldridge, 2011).

The tendency of pits to develop into resource-rich patches depends on the texture and aggregation of the substrate and the extent to which entrained material remains in situ or is winnowed out. Bilby and bettong pits in eastern Australia tended to be relatively deep and cylindricalshaped, and the tendency of these animals to forage in coarse-textured soils means that any litter accumulating in them is likely to be trapped in situ by the mobile sand and unlikely to be removed by wind or water. The landscape-level effects on soil nutrients, however, may be low, given that soil $\mathrm{C}$ and $\mathrm{N}$ pools are substantially less in coarse-textured than finer-textured soils in the plains and swales. We would predict the consequences for soil nutrient pools to be greater in landscapes with soils of higher levels of aggregation and where pit integrity is greater such as the loamy plain and swale soils in Australia and the tarbush and tabosa grass playa in the Chihuahuan Desert.

\section{Conclusions}

Most of the nutrients in desert landscapes are held within the top few centimeters of the soil. It is here that the effects of surface management are most pronounced and where the majority of biological processes are mediated. Given that the zone of maximum faunal activity occurs close to the surface, animal-mediated processes would therefore be expected to be extremely important in this area. Until recently, the emphasis on pedogenesis has largely been on physical and geomorphic processes such as wind and water erosion, freeze-thaw phenomena and other abiotic processes. Our work from semi-arid eastern Australia and arid Northern Chihuahuan Desert provides strong evidence that the effects of soil-disturbing animals are an important geomorphic process operating in near-surface soils. Our results indicate that biological processes are as important, if not more important, in structuring desert landscapes and providing sediment for mobilization than abiotic processes. In functional ecosystems, surfaceforaging vertebrates and their structures contribute to landscape heterogeneity by modulating basic ecosystem resources such as water, soil and nutrients. While some of their activities contribute to heterogeneity at the patch and landscape scales, and are therefore critical for the maintenance of ecosystem processes, others activities lead to landscape instability and therefore degradation. The balance of these two competing processes is, however, highly context dependent.

\section{Acknowledgments}

We are grateful to the Australian Wildlife Conservancy, particularly Sarah Legge and Matt Hayward, and the Arid Lands Consortium, for continued financial and logistical support to undertake various parts of this research. We thank Kris Havstad (ARS-USDA Jornada Range Experimental Station) for allowing us access to field sites and providing office and laboratory equipment. A large number of people helped to assemble the US dataset including Verity Mathes, Ben Duval and Eric Jackson. We thank Erin Roger and David Butler for comments on an earlier draft.

\section{References}

Abensperg-Truan, M., 1991. A study of home-range, movements and shelter use in adult and juvenile echidnas (Monotremata: Tachyglossidae) in Western Australian wheatland reserves. Australian Mammalogy 14, 13-21.

Archer, S.R., 2010. Rangeland conservation and shrub encroachment: new perspectives on an old problem. In: Toit, J.T.D., Kock, R., Deutsch, J.C. (Eds.), Wild rangelands: conserving wildlife while maintaining livestock in semi-arid ecosystems. John Wiley and Sons Ltd, Chichester, UK, pp. 53-97.

Bochet, E., Rubio, J.L., Poesen, J., 1999. Modified topsoil islands within patchy Mediterranean vegetation in SE Spain. Catena 38, 23-44.

Boeken, B., Shachak, M., Gutterman, Y., Brand, S., 1995. Patchiness and disturbance: plant community responses to porcupine diggings in the central Negev. Ecography $18,410-421$.
Buechner, K., 1942. Interrelationship between the pocket gopher and land use. Journal of Mammalogy 23, 346-348.

Butler, D.R., 1995. Zoogeomorphology: Animals as Geomorphic Agents. Cambridge University Press, London.

Chew, R.M., 1979. Consumers as regulators of ecosystems: an alternative to energetics. The Ohio Journal of Science 74, 359-370.

Coetzee, B.W.T., Tincani, L., Wodu, Z., Mwasi, S.M., 2008. Overgrazing and bush encroachment by Tarchonanthus camphoratus in a semi-arid savanna. African Journal of Ecology 46, 449-451.

Dangerfield, J.M., McCarthy, T.S., Ellery, W.N., 1998. The mound-building termite Macrotermes michaelseni as an ecosystem engineer. Journal of Tropical Ecology 14, 507-520.

Darwin, C., 1881. The Formation of Vegetable Mold Through the Action of Worms. Appleton, New York.

De Villiers, A.J., Van Rooyen, M.W., Theron, G.K., 2001. The role of facilitation in seedling recruitment and survival patterns, in the Strandveld Succulent Karoo, South Africa. Journal of Arid Environments 49, 809-821.

Dunkerley, D.L., Brown, K.J., 1995. Runoff and runon areas in a patterned chenopod shrubland, arid western New South Wales, Australia-characteristics and origin. Journal of Arid Environments 30, 41-55.

Duval, B.D., Jackson, E., Whitford, W.G., 2005. Mesquite (Prosopis glandulosa) germination and survival in black-grama (Bouteloua eriopoda) grassland: relations between microsite and heteromyid rodent (Dipodomys spp.) impact. Journal of Arid Environments 62, 541-554.

Eghbal, M.K., Southard, R.J., 1993a. Mineralogy of aridisols on dissected alluvial fans, Western Mojave Desert, California. Soil Science Society of America Journal 57, 538-544.

Eghbal, M.K., Southard, R.J., 1993b. Micromorphological evidence of polygenesis of 3 aridisols, Western Mojave Desert, California. Soil Science Society of America Journal 57, 1041-1050.

Eldridge, D.J., 2004. Mounds of the American badger (Taxidea taxus): significant geomorphic features of North American shrub-steppe ecosystems. Journal of Mammalogy 85, 1060-1067.

Eldridge, D.J., 2011. The resource coupling role of animal foraging pits in semi-arid woodlands. Ecohydrology 4, 623-630.

Eldridge, D.J., James, A.I., 2009. Soil-disturbance by native animals plays a critical role in maintaining healthy Australian landscapes. Ecological Management and Restoration 10, S27-S34.

Eldridge, D.J., Kwok, A.B.C., 2008. Soil disturbance by animals at varying spatial scales in a semi-arid Australian woodland. Rangeland Journal 30, 327-337.

Eldridge, D.J., Mensinga, A., 2007. Foraging pits of the short-beaked echidna (Tachyglossus aculeatus) as small-scale patches in a semi-arid Australian box woodland. Soil Biology and Biochemistry 39, 1055-1065.

Eldridge, D.J., Myers, C.A., 2000. The impact of warrens of the European rabbit (Oryctolagus cuniculus L.) on soil and ecological processes in a semi-arid Australian woodland. Journal of Arid Environments 47, 325-337.

Eldridge, D.J., Whitford, W.G., 2009. Soil disturbance by native animals along grazing gradients in an arid grassland. Journal of Arid Environments 73, 1144-1148.

Eldridge, D.J., Whitford, W.G., Duval, B.D., 2009. Animal disturbances promote shrub maintenance in a desertified grassland. Journal of Ecology 97, 1302-1310.

Eldridge, D.J., Val, J., James, A.I., 2011. Abiotic effects predominate under prolonged livestock -induced disturbance. Austral Ecology 36, 367-377.

Elkins, N.Z., Sabol, G.V., Ward, T.J., Whitford, W.G., 1986. The influence of subterranean termites on the hydrological characteristics of a Chihuahuan desert ecosystem. Oecologia 68, 521-528.

Garkaklis, M.J., Bradley, J.S., Wooller, R.D., 2004. Digging and soil turnover by a mycophagous marsupial. Journal of Arid Environments 56, 569-578.

Geluso, K., 2005. Benefits of small-sized caches for scatter-hoarding rodents: influence of cache size, depth, and soil moisture. Joumal of Mammalogy 86, 1186-1192.

Gile, L.H., Hawley, J.W., Grossman, R.B., 1981. Soils and Geomorphology in the Basin and Range Area of Southern New Mexico-Guidebook to the Desert Project. Memo 39. New Mexico Bureau of Mines and Mineral Resources, Socorro, New Mexico.

Hatough-Bouran, A., 1990. The burrowing habits of desertic Rodents Jaculus jaculus and Gerbillus dasyurus in the Shaumari Reserve in Jordan. Mammalia 54, 341-359.

Herrick, J.E., Whitford, W.G., de Soyza, A.G., Van Zee, J.W., Havstad, K.M., Seybold, C.A. Walton, M., 2001. Field soil aggregate stability kit for soil quality and rangeland health evaluations. Catena 44, 27-35.

Hole, F.D., 1981. Effects of animals on soil. Geoderma 25, 75-112.

Huang, N., 2007. Interrelationships between burrowing animals and arid landscapes. BSc Honours Thesis, University of NSW, 82 pp.

James, A.I., Eldridge, D.J., 2007. Reintroduction of fossorial native mammals potential impacts on ecosystem processes in an Australian desert landscape. Biological Conservation 138, 351-359.

James, A.I., Eldridge, D.J., Hill, B.M., 2009. Foraging animals create fertile patches in an Australian desert shrubland. Ecography 32, 723-732.

Johnson, C.N., 1994. Distribution of feeding activity of the Tasmanian Bettong (Bettongia gaimardi) in relation to vegetation patterns. Wildlife Research 21, 249-255.

Jones, C.G., Lawton, J.H., Shachak, M., 1997. Positive and negative effects of organisms as physical ecosystem engineers. Ecology 78, 1946-1957.

Kerley, G.I.H., Whitford, W.G., 2009. Can kangaroo rat graminivory contribute to the persistence of desertified shrublands? Journal of Arid Environments 73 651-657.

Lavelle, P., Decaëns, T., Aubert, M., Barot, S., Blouin, M., Bureau, F., Margerie, P., Mora, P., Rossi, J.-P., 2006. Soil invertebrates and ecosystem services. European Journal of Soil Biology 42, 3-15. 
Longland, W. S., 1995. Desert rodents in disturbed shrub communities and their effects on plant recruitment. In: Roundy, B.A., McArthur, E.D., Haley, J.S., Mann, D.K. (Compilers). Proceedings: Wildland Shrub and Arid Land Restoration Symposium. Las Vegas, NV. Gen. Tech. Rep. INT-GTR-315. pp. 209-215.

Meadows, P.S., Meadows, A., 1991. The Environmental Impact of Burrowing Animals and Animal Burrows. Symposia of the Zoological Society of London No. 63. Clarendon Press, Oxford.

Nash, M.H., Whitford, W.G., 1995. Subterranean termites: regulators of soil organic matter in the Chihuahuan Desert. Biology and Fertility of Soils 19, 15-18.

Nkem, J.N., de Bruyn, L.A.L., Grant, C.D., Hulugalle, N.R., 2000. The impact of ant bioturbation and foraging activities on surrounding soil properties. Pedobiologia 44, 609-621.

Noble, J.C., 1997. The Delicate and Noxious Scrub: CSIRO Studies on Native Tree and Shrub Proliferation in the Semi-arid Woodlands of Eastern Australia. CSIRO Wildlife and Ecology, Lyneham, ACT.

Noy-Meir, I., 1973. Desert ecosystems: environment and producers. Annual Review of Ecology and Systematics 4, 25-51.

Ognev, S.I., 1947. Mammals of the U.S.S.R. and adjacent countries. Mammals of Eastern Europe and Northern Asia, Vol 5. Israel Progressive Scientist Translation, Jerusalem.

Payne, R.W., Lane, P.W., Digby, P.G.N., Harding, S.A., Leech, P.K., Morgan, G.W., Todd, A.D., Thompson, R., Tunnicliffe Wilson, G., Welham, S.J., White, R.P., 1993. Genstat 5 Release 3 Reference Manual. Oxford University Press, New York.

Randall, J.A., 1993. Behavioral adaptations of desert rodents (Heteromyidae). Animal Behaviour 45, 263-287.

Read, J.L., Carter, J., Moseby, K.M., Greenville, A., 2008. Ecological roles of rabbit, bettong and bilby warrens in arid Australia. Journal of Arid Environments 72, 2124-2130.

Reichman, O.J., Smith, S.C., 1990. Burrows and burrowing behavior by mammals. In: Genoways, H.H. (Ed.), Current Mammalogy. Plenum Press, New York, pp. 197-244.

Richens, V.B., 1966. Notes on digging activity of a northern pocket gopher. Journal of Mammalogy 47, 531-533.

Rismiller, P.D., 1999. The Echidna, Australia's Enigma. Lauter Levin Associates, Connecticut

Robinson, P., 2003. Non-invasive surveys of the short-beaked echidna (Tachyglossus aculeatus) in Uffington State Forest University of Newcastle. Unpublished report.

Roig, V.G., Loyarte, M.M.G., Rosi, M.I., 1988. Ecological analysis of mound formation of the mima type in Rio-Quinto, province of Cordoba. Argentina Studies on Neotropical Fauna and Environment 23, 103-116.
Sherrod, S.K., Seastedt, T.R., 2001. Effects of the northern pocket gopher (Thomomys talpoides) on alpine soil characteristics, Niwot Ridge, CO. Biogeochemistry 55, 195-218.

Snyder, S.R., Crist, T.O., Friese, C.F., 2002. Variability in soil chemistry and arbuscular mycorrhizal fungi in harvester ant nests: the influence of topography, grazing and region. Biology and Fertility of Soils 35, 406-413.

Soholt, L.F., 1977. Consumption of herbaceous vegetation and water during reproduction and development of Merriams Kangaroo Rat, Dipodomys merriami. The American Midland Naturalist 98, 445-457.

Steele, V.R., Temple-Smith, P.D., 1998. Physical structure of warrens of a small colony of southern hairy-nosed wombats Lasiorhinus latifrons. In: Wells, R.T., Pridmore, P.A. (Eds.), Wombats. Surrey Beatty and Sons, Chipping Norton, pp. 113-124.

Steinberger, Y., Whitford, W.G., 1983. The contribution of rodents to decomposition processes in a desert ecosystem. Journal of Arid Environments 6, 177-181.

Urbaniak, S., Whitford, W.G., 1983. Decomposition rates of various quantities of buried litter in a desert. The Southwestern Naturalist 28, 111-112.

Van Auken, O.W., 2009. Causes and consequences of woody plant encroachment into western North American grasslands. Journal of Environmental Management 90, 2931-2942.

Viles, H.A., 1988. Coastal landforms-human activity, geomorphology and ecology in the coastal zone. Progress in Physical Geography 12, 293-301.

Wagner, D., Brown, M.J.F., Gordon, D.M., 1997. Harvester ant nests, soil biota and soil chemistry. Oecologia 112, 232-236.

Weil, R., Islam, K.R., Stine, M.A., Gruver, J.B., Sampson-Liebeg, S.E., 2003. Estimating active carbon for soil quality assessment: a simplified method for laboratory and field use. American Journal of Alternative Agriculture 18, 3-17.

Whitford, W.G., 2002. Ecology of Desert Systems. Academic Press, New York and London.

Whitford, W.G., Kay, F.R., 1999. Biopedturbation by mammals in deserts: a review. Journal of Arid Environments 41, 203-230.

Wood, D.H., 1985. Effectiveness and economics of destruction of rabbit warrens in sandy soil by ripping. Australian Rangeland Journal 7, 122-129.

Zimina, R.P., Zlotin, R.I., 1980. Rol surkov v formirovannii gornikh ekosistem Sredney Azii. In: Frunze, I. (Ed.), , p. 108.

Zimina, R.P., Pogodina, G.S., Urushadeze, T.F., 1970. Landshaftoobrazuyuschaya rol surdov v aridnykh Tian-Sanya i Pamira. Materialy k poznanyu fauny i flory SSSR (MOIP) 45, 177-191. 